Jurnal Bimbingan Konseling
$10(2)(2021): 89-98$
UNNES

\title{
Mindfulness and Student Engagement: The Mediation Effect of Self Esteem
}

\author{
Munik Yuni Artika $^{1 凶}$, Sunawan Sunawan ${ }^{2}$, Awalya Awalya ${ }^{2}$ \\ ${ }^{1 .}$ Universitas Islam Negeri Raden Intan Lampung, Indonesia \\ 2. Pascasarjana Universitas Negeri Semarang, Indonesia
}

\begin{tabular}{|c|c|}
\hline Article Info & Abstract \\
\hline $\begin{array}{l}\text { History Articles } \\
\text { Received: } \\
\text { 15 Mei } 2021 \\
\text { Accepted: } \\
\text { 25 June 2021 } \\
\text { Published: } \\
30 \text { August } 2021 \\
\text { Keywords: } \\
\text { Mindfulness, } \\
\text { Self-Esteem, Student } \\
\text { Engagement }\end{array}$ & $\begin{array}{l}\text { Student engagement in learning is essential in creating active, creative, and fun } \\
\text { learning. Unfortunately, not all students are engaged cognitively, emotionally, } \\
\text { and behaviorally in learning. This study intends to prove that self-esteem can } \\
\text { mediate the relationship between mindfulness and student engagement. This } \\
\text { correlational study involved } 469 \text { students from four Senior/Vocational High } \\
\text { schools in East Lampung Regency. The result of this study revealed that } \\
\text { mindfulness predicts higher self-esteem. Mindfulness predicts student } \\
\text { engagement. Self-esteem predicts student engagement. Mindfulness also } \\
\text { increases student engagement through increased self-esteem. The implications } \\
\text { of this study suggest the importance of appreciating student's mental state and } \\
\text { performance in the learning process. }\end{array}$ \\
\hline
\end{tabular}

$\bowtie$ Correspondence address:
Karyatani, Kec. Labuhan Maringgai, Kab Lampung Timur,
Lampung 34198, Indonesia

p-ISSN 2252-6889

e-ISSN 2502-4450

E-mail: munikyuniartika12@gmail.com 


\section{INTRODUCTION}

Student engagement is crucial in academic activities since students are required to be actively involved in the learning process (Dwistia, Purwanto,\& Sunawan, 2016). Student engagement is defined as a multi-aspect, often assessed regardingwhat students do, think, and feel that have direct relevance to academic tasks (Fredricks, Reschly, \& Christenson, 2019).

Student engagement alludes to active participation shown by students. Specifically, student engagement encompassesthree important dimensions of cognitive, affective, and behavioral engagement (Fredricks, Blumenfeld, \& Paris, 2004). Student engagement in school activities has contributed to improved student's learning abilities as well as learning new things, be it in teaching and learning activities or activities outside the classroom (Dharmayana, Kumara, \& Wirawan, 2012). Student engagement can be seen through student's concentration, attractiveness, and comfort in receiving learning (Widyaswara, Wardono \& Asih, 2019). On the other hand, students with low engagement are seen from their passiveness, reluctance, looking bored, giving up easily, and showing negative emotions such as anger, blame, and rejection (Skinner \& Belmont, 1993). Itcan also be seen through their truant behavior, chatting while the teacher is teaching, doing things that have nothing to do with learning activities, and not dressing according to school rules (Frederick, Bluemenfeld \& Paris, 2004). In fact, students who enjoy the learning process tend to have a good perception of their academic performance (Medlin \& Faulk, 2011). Lester (2013) also asserts that student engagement can improve learning and promote better academic outcomes.

The learning process must consider student's learning experience and student's need to be directly involved in learning (Pekrun \& Linnenbrink-Garcia, 2012) since the learning process in the classroom basically will not work well if there is no engagement from students (Kurnaedi. Sugiharto \& Sunawan, 2020).
Self-esteem predicts student engagement (Virtanen et al., 2016). Explicitly, Rosenberg (in Puspita, Mugiarso, \& Mulawarman, 2019) states that self-esteem refers to an individual's evaluation made by paying attention to oneself. Self-esteem is considered as individual behavior that affects a person's efforts to perform. Putri, Ahied, and Rosidi (2019 also argue that learning will be more effective if students not only develop their cognitive but also their affective, especially their student self-esteem. Students with high self-esteem will be able to respect themselves and see positive things that students can do for their future learning success. Selfesteem gives student's ability to see themselves that can be transferred to the way they see school relationships and school relevance (Virtanen et al., 2016). This research is expected to complement previous findings that Zhang, Feng, and Li (2021) suggest to further elaborate on the internal mechanisms of self-esteem as a mediator to maintain and increase student engagement in the learning process.

Referring to early description, mindfulness is believed to predict self-esteem (Rasmussen \& Pidgeon, 2011) and student engagement (Minkos, Chafouleas, Bray \& LaSella, 2018). Kabat-Zinn (in Walach et al., 2006) defines mindfulness as the process of paying attention in certain ways such as being aware, focusing on the present moment, and being non-judgmental. Mindfulness has five aspects of observing, describing, doing with awareness, receiving without judging, and not being reactive (Baer, Smith, \& Allen, 2004). Therefore, mindfulness acts as individual awareness that helps individuals to get rid of automatic thoughts and unhealthy behaviors, and the ability to regulate their behavior (Bajaj, Gupta \& Pande, 2016).

Mindfulness skills offer assistance for individuals to accept themselves and to extendtheir perceptions of who they are, how valuable they are, and strengthen their selfesteem (Jang \& Jeon, 2015). The findings of a study conducted by Thompson and Waltz (2008) reveal that mindfulness offers a way to 
foster unconditional self-acceptance and shift emphasis to self-esteem as a valuable measure.

Mindfulness also provides benefits for increasing student engagement in learning. According to Minkos et al. (2018), mindfulness has the potential to be an effective way to increase student's academic engagement. Mindfulness acts as a method that helps students become more aware of learning situations making them more engaged in learning (Lin, 2020). Empirical evidence regarding research in mindfulness and student engagement is still limited. Nonetheless, this study has contributed to the growing literature on mindfulness in academic settings. Bellinger, DeCaro, and Ralston (2015) provided initial support for the importance of mindfulness in academic settings. However, the study has not confirmed whether mindfulness is useful for the academic performance of cognitive and affective functions from student engagement. To address this gap, this study seeks to clarify the mediating role of self-esteem in the relationship between mindfulness and student engagement.

\section{METHOD}

There were 469 students involved as respondents in this study. They consisted of 163 male students and 306 female students with an age range of 15-18 years. They came from Senior/ vocational High Schools in East Lampung Regency. Participants were selected using cluster random sampling.

There were three scales used in the study. They arethe student engagement scale, selfesteem scale, and mindfulness scale. The scales used in this study were adapted from published instruments. Therefore, a back-translation procedure was appliedtoadapt all the scales for the purpose of this study.

Student engagement in the study was measured using the University Student Engagement Inventory (USEI)developed by Fredricks et al. (Fredricks etal., 2004; Maroco, Maroco, Campos,\& Fredricks, 2016). The USEI aims to measure three components of student engagement of emotional engagement, cognitive engagement, and behavioral engagement. Each component consists of 5 items. There were 15items. There were5 options, namely (1) never, (2) rarely, (3) sometimes, (4) often, (5) always. The results of the validity test on the USEI showed that the 15 statement items used in this study met the criteria and were declared valid $(\mathrm{KMO}=0.872$, Sig. 2-tailed <0.05). While the reliability test on each indicator showed the Cronbach"s Alpha values (emotional engagement $=0.656$, cognitive engagement $=$ 0.763 , and behavioral engagement $=0.769$ ) that were declared reliable. Hence, this scale can be used in research.

Self-esteem was measured using the Rosernberg Self-Esteem Scale (RSES) developed by Rosernberg (1965). RSES aims to measure aspects of self-esteem, including self-acceptance and self-respect. The RSES consists of 10 items with a 4-point Likert scale, ranging from (1) strongly disagree, (2) disagree, (3) agree, and (4) strongly agree. The results of the validity test on the RSES showed that the 10 items used in this study met the criteria and were declared valid $(\mathrm{KMO}=0.733$, Sig. 2 tailed <0.05). While the reliability test on each indicator obtained Cronbach's Alpha value (self-acceptance = 0.562 , self-respect $=0.609$ ) that were declared reliable. Thus, this scale can be used in research.

Mindfulness was measured using The Five Facet Mindfulness Questionnaire (FFMQ) developed by Baer et al., (2006). This scale aims to measure the five sides of mindfulness such as observing, describing, acting with awareness, accepting without judgment, and non-reactivity. Each side of mindfulness consists of 4 items. Thus, there were 20items. They were given 5 options, namely; (1) never, (2) seldom, (3) sometimes, (4) often, and (5) very often. The results of the validity test on the FFMQ show that 20 itemsused in this study met the criteria and were declared valid $(\mathrm{KMO}=0.870$, Sig. 2 tailed $<0.05$ ). While the reliability test on each indicator obtained Cronbach's Alpha values (observing $=0.691$, describing $=0.793$, acting with awareness $=0.702$, accepting without judgment $=0.744$, non-reactivity $=0.655$ ) that 
were declared reliable. Therefore, this scale can be used in research.

In analyzing the data, this study used a mediator analysis using the PROCESS application developed by Andrew F. Hayes (2013). The data analysis technique in this study used a regression-based path-analytic framework.

Table 1. Data Description

\begin{tabular}{llll}
\hline Variable & N & M & SD \\
\hline Mindfulness & 469 & 61.92 & 6.65 \\
Student Engagement & 469 & 53.00 & 8.77 \\
Self-esteem & 469 & 28.83 & 3.83 \\
\hline
\end{tabular}

Hypothesis testing was carried out using mediator analysis using the PROCESS application developed by Andrew F. Hayes

\section{RESULTS AND DISCUSSION}

The description of the data in this study showed the mean and standard deviation of mindfulness $(\mathrm{M}=61.92 ; \mathrm{SD}=6.65)$, student engagement $(\mathrm{M}=53.00 ; \mathrm{SD}=8.77)$, and student self-esteem $(\mathrm{M}=28.83 ; \mathrm{SD}=3.83)$. A larger mean value implies a good representation for the data distribution. In detail, the data is presented in Table 1.
(2013). Mediation analysis using bias-corrected bootstrap, $\mathrm{N}=5000$ with $95 \%$ confidential interval. The results are shown in Table 2.

Table 2. The Effect of Self-Esteem as a Mediator Variable.

\begin{tabular}{lcccccccccc}
\hline Predictors & $\mathrm{B}$ & $\mathrm{T}$ & $P$ & $\mathrm{Se}$ & $\mathrm{LLCI}$ & $\mathrm{ULCI}$ & $\mathrm{R}$ & $\mathrm{R}^{2}$ & $\mathrm{~F}$ & $P$ \\
\hline Criterium : Self-esteem & & & & & & & 0.26 & 0.06 & 32.97 & $<0.01$ \\
Mindfulness & 0.15 & 5.74 & $<0.05$ & 0.02 & 0.20 & 0.20 & & & & \\
\hline Criterium: Student Engagement & & & & & & 0.43 & 0.18 & 51.83 & $<0.01$ \\
Mindfulness & 0.22 & 3.94 & $<0.05$ & 0.06 & 0.11 & 0.34 & & & & \\
Self-esteem & 0.80 & 8.06 & $<0.01$ & 0.10 & 0.60 & 0.99 & & & & \\
\hline Total Effect & 0.34 & 5.83 & $<0.05$ & 0.06 & 0.23 & 0.46 & & & \\
Indirect & 0.12 & & & 0.03 & 0.07 & 0.17 & & & \\
\hline
\end{tabular}

Table 2 shows that mindfulness is positively related to self-esteem $(B=0.15$, $\mathrm{p}<0.05, \mathrm{~F}=32.97, \mathrm{p}<0.01)$. From the coefficient of determination $(\mathrm{R} 2=0.06)$, mindfulness has an effect of $6.5 \%$ on self-esteem.

Furthermore, student engagement was positively explained by mindfulness and selfesteem (R2=0.18, $\mathrm{F}=51.83, \quad \mathrm{p}<0.01)$, Specifically, student engagement was positively predicted by mindfulness ( $\mathrm{B}=0.22, \mathrm{p}<0.05$ ). Meanwhile, self-esteem and student engagement have a positive relationship $(\beta=0.80, \mathrm{p}<0.01)$. From the coefficient of determination (R2= 0.18 ), mindfulness and self-esteem have an effect of $18.2 \%$ on student engagement. 


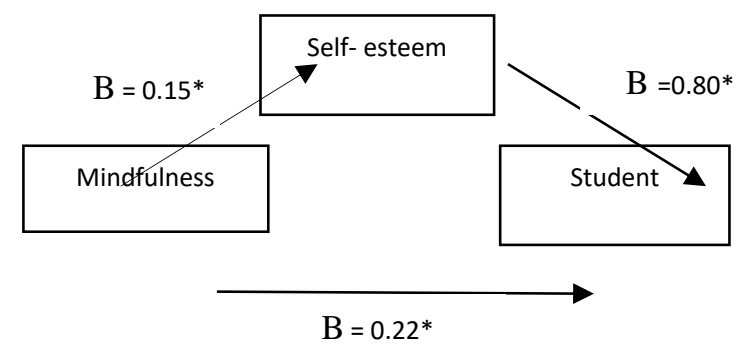

Figure1.Model of Self-Esteem Mediates Mindfulness on Student Engagement

The findings of this study prove that mindfulness predicts self-esteem. This is in contrast with the findings of Rasmussen and Pidgeon (2011) that mindfulness contributes positively to healthy self-esteem. The research results conducted by Pepping et al. (2013) show the link between mindfulness and self-esteem that mindfulness has a direct positive effect on self-esteem. While research carried out by Bajaj, Gupta, and Pande (2016) revealed that individuals with high levels of mindfulness tend to have high self-esteem. Conceptually, mindfulness involves a non-judgmental attitude about themselves, being open to one's emotions, thoughts, and experiences that in turn increases the individual's self-esteem (Baer, Smith, Hopkins, Krietemeyer, \& Toney, 2006). Individuals with higher levels of mindfulness are less likely to struggle with situations they cannot change. Individuals accept their emotions, thoughts, and situations. They do not measure their worth by the standards of others. Therefore, individuals with higher levels of mindfulness have greater self-acceptance and self-esteem (Thompson \& Waltz, 2007). In addition, individuals with mindfulness can manage their and other's emotions with the tendency to focus on the present (Park, \& Dhandra, 2017), thus leading to an increased ability to restrain from potentially negative thoughts about themselves that ultimately leads to increasing self-esteem (Bajaj, Gupta \& Pande, 2016).

This study proves that mindfulness predicts student engagement. This is in line with the previous findingof a study conducted by
Minkos, Chafouleas, Bray, and LaSella (2018) that mindfulness is an effective way to increase student academic engagement. A study carried out by Lin (2020) confirmed mindfulness as a positive predictor of students'learning engagement, especially in English lessons. The results of the research confirm that mindfulness can help students become aware of the learning situation and be more involved in learning. Meanwhile, another finding (Bellinger, DeCaro,\& Ralston, 2015) shows that mindfulness is useful for supporting academic performance in general. However, their research has not confirmed the effect of mindfulness on academic performance from the emotional and cognitive functions that can be observed from student engagement. This study succeeded in proving the contribution of mindfulness to student engagement from the emotional and cognitive aspects.

Student engagement in learning is prominent to create active, creative, and fun learning. Good student engagement is the main requirement for a good academic performance. It also maximizes learning activities in the classroom. Optimal engagement focuses on three components of cognitive, emotional, and behavioral engagement (Fredricks, Blumenfeld, \& Paris, 2004). These three components will interact dynamically within students as a form of embodiment of motivation, which then directs students to be energetic, directed, and persistent when experiencing difficulties in academic activities (Ariani, 2019; Connell, \& Wellborn, 1991). According to Ladd and Dinella (in Reeve, 2012), student engagement can support the learning process to run well. There is no learning process without the student's active participation. Therefore, in the teaching and learning process, students need to build their knowledge by focusing and interacting directly with objects during class. This will have a major influence on the process of thinking, emotional, and social development.

To strengthen student engagement in learning, mindfulness is very important to contribute to refreshing students' cognitive and emotions. Itis manifested in fun learning 
activities. Cruchon (in Ager, Albrecht,\& Cohen, 2015) explicitly states that mindfulness potentially helps students feel more relaxed, less afraid, and happier while studying. Mindfulness can help students develop a greater awareness of their body, mind, and emotions. Mindfulness is an important center in changing students' thinking and emotional responses (Jannah, 2019). Mindfulness can encourage changes in academic performance, such as certain cognitive skills (attention, concentration, and memory), positive feelings and emotional balance that can support optimal performance even in demanding situations (Franco et al., 2010). In addition, mindfulness can create strong thoughts that lead students to be more resilient in learning (Anindita, \& Etikariena, 2020). In other words, when students have mindfulness, students will enjoy the learning process more, which then leads students to engagement and better learning performance.

The results of this study prove that selfesteem predicts student engagement. The results of this study are in line with Virtanen et al. (2016) that confirmed the relationship of students' self-esteem, affective and cognitive engagement. However, a study by Zhang, Feng, and Li (2021) suggests further elaborate on the internal mechanisms that enable self-esteem as a mediator to maintain and increase student engagement in the learning process. This study succeeded in proving the mediation of selfesteem on student engagement

Students'engagement will be stronger if they have good self-esteem during the learning process. Self-esteem is the main component of self-evaluation whosean important role in student development (Palupi, Sunawan, \& Murtadho, 2020). Students who show a positive evaluation of themselves will be more committed and more actively participate in academic activities at school (Battle et al., 1988; Mai \& Asma'A, 2016). In addition, a positive evaluation of self-esteem will lead students to a self-concept that results in greater responsibility and motivation from students towards the academic environment enabling them to maintain enthusiasm and persistence despite learningproblems (Martin et al., 2021). Thus, how students evaluate themselves can be shifted towards student engagement in a more effective learning process.

Self-esteem can link the interrelationships between mindfulness and student engagement. When mindfulness and self-esteem are integrated, it increases engagement. Mindfulness, which focuses on the well-being of the individual, will form a positive selfevaluation (Bajaj, Gupta,\& Pande, 2016). This provides benefits for students' cognitive and affective stability which will ultimately result in greater responsibility and motivation for students towards their academic achievement (Martin, et al., 2021). Thus, the results of this study indicate that mindfulness can increase student engagement through increasing selfesteem.

The results of this study have significant implications for guidance and counseling. Student engagement in the learning process implies reciprocity between teachers and students in academic activities. It createsa conducive learning environment. This study focuses on the importance of respecting students' inner state and behavioral performance. Therefore, it is suggested that counselors and teachers pay more attention to students' selfesteem in daily life. In particular, counselors should provide timely psychological care for students who are pressured during the learning process. When students' self-esteem increases, students can evaluate things to develop their learning capacity. Furthermore, school counselors need to provide students with an understanding that mindfulness is neededin daily life, including in the learning process. With mindfulness, students can focus more on what they are encountering, especially when students are at school.

The study suffers from the limitation that the scope of research is limited to exploring the relationship of mindfulness to student engagement through self-esteem. Thus, it does not provide any form of intervention. Therefore, it is hoped that the results of this study can be used as a basis for experimental studies. Because 
mindfulness also acts as a self-skill. It can be manifested in the form of daily or weekly practice to increase self-esteem and student engagement.

\section{CONCLUSION}

This finding confirms the indirect effect between mindfulness and student engagement through self-esteem. This study examines the interrelationships between mindfulness, selfesteem, and student engagement. Therefore, it is expected that the results of this study can be used as a basis for experimental studies. Since mindfulness also acts as a self-skill, it can be manifested in the form of daily or weekly practice to increase students' self-esteem and engagement.

\section{REFRENCES}

Ager, K., Albrecht, N. J., \& Cohen, M. (2015). Mindfulness in schools research project: exploring students' perspectives of mindfulness - what are students' perspectives of learning mindfulness practices at school? Psychology, 6(07), 896.

DOI: https://doi.org/10.4236/psych.2015.670 88

Anindita, A., \& Etikariena, A. (2020). Hubungan trait mindfulness dan keterikatan kerja dengan melibatkan peran mediasi modal psikologis. Jurnal Psikogenesis, 8(1), 1-17. Retrieved from file:///C:/Users/User/AppData/Local/ Temp/1039-3049-1-PB.pdf

Ariani, L. (2019) Keterikatan siswa (student engagement) di sekolah sebagai salah satu upaya peningkatan keberhasilan siswa di sekolah. Retrieved from: http://fppsi.um.ac.id/wpcontent/upload s/2019/07/13-keterlibatan-siswa-studentengagement-di-sekolah-sebagai-salahsatu-upaya-peningkatan-103-110.pdf

Baer, R. A., Smith, G. T., \& Allen, K. B. (2004). Assessment of mindfulness by self-report: The kentucky inventory of mindfulness skills. Assessment, 11(3), 191-206. DOI: https://doi.org/10.1177\%2F1073191104 268029

Baer, R. A., Smith, G. T., Hopkins, J., Krietemeyer, J., \& Toney, L. (2006). Using self-report assessment methods to explore facets of mindfulness. Assessment, 13, 27-45. DOI: https://doi.org/10.1177/1073191105283 504

Bajaj, B., Gupta, R., \& Pande, N. (2016). Selfesteem mediates the relationship between mindfulness and well-being. Personality and Individual Differences, 94, 96-100. DOI:

https://dois.org/10.1016/j.paid.2016.01. 020

Bellinger, D. B., DeCaro, M. S., \& Ralston, P. A. (2015). Mindfulness, anxiety, and high-stakes mathematics performance in the laboratory and classroom. Consciousness and Cognition, 37, 123132.

DOI:https://doi.org/10.1016/j.concog.2 015.09 .001

Battle, J., Jarratt, L., Smit, S., \& Precht, D. A. N. (1988). Relations among self-esteem, depression, and anxiety of children. Psychological Reports, 62(3), 999-1005. DOI:

https://doi.org/10.2466\%2Fpr0.1988.62. 3.999

Connell, J. P., \& Wellborn, J. G. (1991). Competence, autonomy, and relatedness: A motivational analysis of self-system processes. InM. Gunnar \& L. A. Sroufe (Eds.), Minnesota Symposium on Child Psychology (Vol. 23). Chicago: University of Chicago Press.

Dharmayana, I. W., Kumara, A., \& Wirawan, Y. G. (2012). Keterikatan siswa (keterikatan siswa) sebagai mediator kompetensi emosi dan prestasi akademik. Jurnal Psikologi,39(1), 7694.DOI: https://doi.org/10.22146/jpsi.6968

Dwistia, H., Purwanto, E., \& Sunawan, S. (2016). Keefektifan konseling kelompok 
dengan strategi self management dalam meningkatkan classroom engagement siswa. Jurnal Bimbingan Konseling, 5(2), 113-118.

DOI: https://doi.org/10.15294/jubk.v5i2.1402 8

Franco, C., Mañas, I., Cangas, A. J., \& Gallego, J. (2010, September). The applications of mindfulness with students of secondary school: Results on the academic performance, self-concept and anxiety. In world summit on knowledge society (pp. 83-97). Springer, Berlin, Heidelberg. Retrieved from: https://link.springer.com/chapter/10.10 07/978-3-642-16318-0_10

Fredricks, J. A., Blumenfeld, P. C., \& Paris, A. H. (2004). School engagement: Potential of the concept, state of the evidence. Review of Educational Research, 74(1), 59-109. DOI:

https://doi.org/10.3102\%2F0034654307400105 9

Fredricks, J. A., Reschly, A. L., \& Christenson, S. L. (2019). Interventions for keterikatan siswa: Overview and state of the field. In Handbook of keterikatan siswa interventions (pp. 1-11). Academic Press. DOI: https://doi.org/10.1016/B978-012-813413-9.00001-2

Hayes, Andrew F. (2013). Introduction to Mediation, Moderation, and Conditional Process Analysis: A Regression-Based Approach. New York, NY: The Guilford Press

Jannah, A. M. (2019). Hubungan mindfulness dan penerimaan diri pada remaja dengan orang tua tunggal (Doctoral dissertation, University of Muhammadiyah Malang). Retrieved from: https://eprints.umm.ac.id/48287/

Jang, H. J., \& Jeon, M. K. (2015). Relationship between self-esteem and mental health according to mindfulness of university students. Indian Journal of Science and Technology, 8(21), 1. DOI:

https://doi.org/10.17485/ijst/2015/v8i21/7845 9
Kurnaedi, N., Sugiharto, D. Y. P., \& Sunawan, S. (2020). The effectiveness of mindfulness deep breathing in classical format to increase students' academic engagement. Jurnal Bimbingan Konseling, 9(1), 29-30. DOI: https://doi.org/10.15294/jubk.v10i1.351 46

Lester, Frank K. 2013. Though about researchon mathematical problem-solving instruction. Jurnal TME, vol 10 no $1 \& 2$, ISSN 1551-3440, pp.245-278. Retrieved from:

https://scholarworks.umt.edu/tme/vol10 /iss1/12/

Levine, G. (2008). A Foucaultian approach to academic anxiety. Educational studies, 44(1), 62-76. DOI: https: //doi.org/10.1080/00131940802225101

Lin, Y. T. (2020). The interrelationship among psychological capital, mindful learning, and english learning engagement of university students in Taiwan. SAGE Open, $\quad 10(1), \quad$ DOI: https://doi.org/10.1177/2158244020901 603

Mai, M. Y., \& Asma'A, A. F. A. (2016). Modeling the relation between selfesteem, loneliness and engagement as factors of children achievement in science. European Journal of Social Science Education and Research, 3(1), 107-120. DOI: https://dx.doi.org/10.26417/ejser.v6i1.p 107-120

Maroco, J., Maroco, A. L., Campos, J. A. D. B., \& Fredricks, J. A. (2016). University student's engagement: Development of the university student's engagement inventory (USEI). Psicologia: Reflexão e Crítica, 29(1), 21. Retrieved from:

https://link.springer.com/article/10.1186/s411 55-016-0042-8

Martín, A. B. B., del Carmen Pérez-Fuentes, M., Jurado, M. D. M. M., Martínez, Á. M., Márquez, M. D. M. S., Sisto, M., \& Linares, J. J. G. (2021). Emotional intelligence and academic engagement in 
adolescents: The mediating role of selfesteem. Psychology research and behavior management, 14, 307. DOI: https://doi.org/10.2147/PRBM.S302697

Medlin, B., \& Faulk, L. (2011). The relationship between optimism and engagement: the impact on student performance. Research in Higher Education Journal, 13. Retrieved from: https://eric.ed.gov/?id=EJ1068808

Minkos, M. L., Chafouleas, S. M., Bray, M. A., \& LaSalle, T. P. (2018). Brief report: A preliminary investigation of a mindful breathing intervention to increase academic engagement in an alternative educational setting. Behavioral Disorders, 43(4), 436-443. DOI: https://doi.org/10.1177/0198742917740 870

Palupi, E. P. D., Sunawan, S., \& Murtadho, A. (2020). The effectiveness of group counseling with stress inoculation training to improve student's self-esteem. Jurnal Bimbingan Konseling, 9(3), 164-168. DOI: $10.15294 /$ jubk. v913,43586

Park, H. J., \& Dhandra, T. K. (2017). The effect of trait emotional intelligenceon the relationship between dispositional mindfulness and self-esteem. Mindfulness, 8(5), 1206-1211. Retrieved from:

https://link.springer.com/article/10.1007 /s12671-017-0693-2

Pekrun, R., \& Linnenbrink-Garcia, L. (2012). Academic emotions and students' engagement, to SL Christenson, AL Reschly, \& C. Wylie (Eds.), The Handbook of research on keterikatan siswa (pp. 259-282). Retrieved from: https://link.springer.com/chapter/10.10 07/978-1-4614-2018-7_12

Pepping, C. A., O’Donovan, A., \& Davis, P. J. (2013). The positive effects of mindfulness on self-esteem. The Journal of Positive Psychology, 8(5), 376-386. DOI: https://doi.org/10.1080/17439760.2013. 807353
Puspita, D. A., Mugiarso, H., \& Mulawarman, M. (2019). Penerapan layanan bimbingan kelompok dengan pendekatan experiential learning untuk meningkatkan self-esteem. Indonesian Journal of Guidance and Counseling: Theory and Application, 8(1), 7-12. DOI: https://doi.org/10.15294/ijgc.v7i2.19843

Putri, I. N., Ahied, M., \& Rosidi, I. (2019). Pengaruh model pembelajaran ARCS (Attention, Relevance, Confidence, Satisfaction) terhadap self esteem siswa. Natural Science Education Research, 2(1), 1-7. Retrieved from: https://journal.trunojoyo.ac.id/nser/arti cle/view/4216/3697

Rasmussen, M. K., \& Pidgeon, A. M. (2011). The direct and indirect benefits of dispositional mindfulness on self-esteem and social anxiety. Anxiety, Stress, \& Coping, 24(2), 227-233. DOI: https://doi.org/10.1080/10615806.2010. 515681

Reeve, J. (2012). Handbook of research onstudent engagement. Journal of Educational psychology. 24(14). 149-172. DOI: 10.1007/978-1-4614-2018-7_7

Rosenberg, M. (1965). Rosenberg self-esteem scale (RSES). Acceptance and commitment therapy. Measures Package, 61(52), 18. Retrieved from: file:///C:/Users/User/AppData/Local/ Temp/ACTmeasures.pdf

Skinner, E. A., \& Belmont, M. J. (1993). Motivation in the classroom: Reciprocal effects of teacher behavior and student engagement across the school year. Journal Of Educational Psychology, 85(4), $\quad 571 . \quad$ DOI: https://doi.org/10.1037/00220663.85.4.5 71

Susanti, P. D., Wibowo, M. E. W. M. E., \& Mulawarman, M. (2019). The effectiveness of acceptance and commitment therapy counseling and mindfulness-based cognitive counseling to reduce school burnout. Jurnal Bimbingan Konseling, 8(4), 173-178. DOI: 
https://doi.org/10.15294/jubk.v9i2.3435 2

Thompson, B. L., \& Waltz, J. A. (2008). Mindfulness, self-esteem, and unconditional self-acceptance. Journal of Rational-Emotive \& Cognitive-Behavior Therapy, 26(2), 119-126. DOI: https://doi.org/10.1007/s10942-0070059-0

Virtanen, T. E., Kiuru, N., Lerkkanen, M. K., Poikkeus, A. M., \& Kuorelahti, M. (2016). Assessment of student engagement among junior high school students and associations with selfesteem, burnout, and academic achievement. Journal for Educational Research Online, 8(2), 136-157. URN: http://nbn-

resolving.org/urn:nbn:de:0111-pedocs124

Widyaswara, I. B., Wardono, W., \& Asih, T. S. N. (2019). Mathematical literacy ability viewed from keterikatan siswa on formulate share listen create model with reciprocal teaching approach assisted by edmodo. Unnes Journal of Mathematics Education Research, 8(2), 188-194.
Retrieved from: https://journal.unnes.ac.id/sju/index.ph $\mathrm{p} / \mathrm{ujmer} /$ article/view/28093

Walach, H., Buchheld, N., Buttenmüller, V., Kleinknecht, N., \& Schmidt, S. (2006). Measuring mindfulness-the Freiburg mindfulness inventory (FMI). Personality and Individual Differences, 40(8), 15431555.

DOI: https://doi.org/10.1016/j.paid.2005.11.0 25

Wijaya, M., Sofah, R., \& Hakim, I. A. (2019). Tingkat kecemasan belajar pada peserta didik yang memiliki prestasi akademik rendah di kelas $\mathrm{x}$ SMK Negeri 4 Palembang. Jurnal Konseling Komprehensif: Kajian Teori dan Praktik Bimbingan dan Konseling, 6(1), 40-48. Retrieved from: file:///C:/Users/User/AppData/Local/ Temp/267824945.pdf

Zhang, F., Feng, S., \& Li, J. (2021). How does future focus promote study engagement? A moderated mediation model of selfesteem and dispositional awe. Psychology in the Schools, 58(1), 203-216. DOI: https://doi.org/10.1002/pits.22439 